\title{
Małgorzata Mikut
}

Uniwersytet Szczeciński

\section{Recenzja książki: Dorota Pauluk, Ukryte programy uniwersyteckiej edukacji i ich rezultaty. Doświadczenia studentów pedagogiki, Kraków 2016, ss. 344}

Umieszczenie w centrum zainteresowań badawczych poznania i zdiagnozowania zjawiska, które z założenia i z racji swojej specyfiki pozostaje w ukryciu, to zadanie dla odważnego i wnikliwego badacza. Bez wątpienia do takich osób należy Dorota Pauluk, dzięki podjęciu przez nią trudnych do uchwycenia (niejawnych) obszarów edukacji uniwersyteckiej oraz ich rezultatów z perspektywy doświadczających go podmiotów, czyli studentów. Autorka monografii dokonała tego, podejmując się analizy treści 319 esejów na temat: "czego uczą studia?”, napisanych przez studentów pedagogiki I i II stopnia trzech specjalności, których łączy studiowanie na tym samym uniwersytecie. Pytanie o to samych uczestników edukacji akademickiej pozwala na poznanie całego spektrum działań studenckich:

To oni przez wiele lat, dzień po dniu, przyswajają normy, wartości, dyspozycje, nieformalne oczekiwania, rutynowe zachowania będące częścią życia instytucji, jaką jest uniwersytet. Zdobywają bogaty bagaż doświadczeń edukacyjnych, które na swój niepowtarzalny sposób zapośredniczają (s. 14-15).

Uzyskany materiał empiryczny jest imponujący, tak samo jak i wiedza (ok. 400 pozycji bibliograficznych) Doroty Pauluk w zakresie fenomenu programu ukrytego, czego dowodem jest obszerna monografia naukowa składająca się z ośmiu rozdziałów. W pierwszym rozdziale ujawniona jest złożoność i nieostrość pojęcia hidden curriculum. Akcentowany jest także jego amorficzny charakter. Autorka wychodzi od genezy i kontrowersji związanych z tym terminem, następnie dokonuje prezentacji różnych stanowisk teoretycznych. Na podkreślenie zasługuje bardzo dobra orientacja autorki w dorobku zagranicznych autorów w omawianym zakresie. W wyniku wnikliwej refleksji dokonuje ona autorskiej rekonstrukcji stanu wiedzy na temat ukrytego programu oraz wskazuje na jego tropy, ślady i rezultaty w polskiej literaturze.

Rozdział drugi zatytułowany Obraz studenta $w$ zmieniajacych się kontekstach życia - tradycja i nowoczesność to przekrojowa prezentacja roli studenta $\mathrm{w}$ zmieniającym się modelu uniwersytetu $\mathrm{w}$ aspekcie historycznym i z perspektywy wybranych modeli rozwoju. Wa- 
lory tego rozdziału podnosi ukazanie przez autorkę charakterystyki okresu rozwojowego, w jakim znajdują się w większości studenci stacjonarni. Czas studiów to zawiła droga do osiągnięcia pełnej dojrzałości. Jak słusznie zauważa Dorota Pauluk:

Dla wielu studentów szkoła wyższa to pasaż, w którym chcą przeczekać trudną sytuację na rynku pracy, bolesne zderzenie z wyzwaniami współczesnej rzeczywistości, odroczyć powzięcie decyzji o wejściu w stały związek, podjęciu ról rodzicielskich. Istnieje przy tym społeczne przyzwolenie dla studiujących, aby ten okres młodości wydłużyć i odsunąć czas podjęcia ról osoby dorosłej po to, aby lepiej przygotować się do wykonywania zawodów wymagających wiedzy i specjalistycznych umiejętności (s. 85).

Rozdział domyka charakterystyka specyfiki pokolenia studentów uwikłanego w pułapki wolności, wielości ofert i propozycji. Autorka świetnie oddaje stan ducha współczesnej wstępującej z dużą ostrożnością w dorosłość generacji, która niejednokrotnie pozostaje osamotniona w swoich wyborach:

[...] doświadczenia młodych dorosłych są jeszcze niewystarczające, aby radzić sobie z wyzwaniami dorosłości. Konflikty i dylematy prowokują zmiany w kierunku wyższych poziomów rozwoju, ale też mogą utrudniać budowanie stabilnej i zintegrowanej tożsamości, zwłaszcza wtedy, gdy nie uzyska się odpowiedniego wsparcia społecznego, albo tego wsparcia było się pozbawionym we wcześniejszych fazach życia (s. 90).

Młodzież wstępująca $w$ mury uczelni próbuje odnaleźć się w nowym miejscu, przyjmując różne strategie radzenia sobie $\mathrm{z}$ wymogami edukacji akademickiej i wykorzystując doświadczenia niejednokrotnie z wcześniejszych etapów kształcenia. Autorka podkreśla jednak, że czas studiów to odrębny etap życia, wskazując na rolę akademickiego środowiska edukacyjnego w stwarzaniu warunków dla rozwoju studenta. To wyjaśnia wyodrębnienie trzeciego rozdziału charakteryzującego warunki stymulujące i utrudniające rozwój studenta. Dorota Pauluk wskazuje jednak na niebezpieczne transformacje uniwersytetu i jego uwikłania w prawa rynku utrudniające rozwój:

Pod wpływem przemian społecznych i kulturowych uniwersytet przestaje odróżniać się od innych typów szkół wyższych oraz niższego poziomu, zatraca ukształtowaną na przestrzeni wieków tożsamość. Stara się godzić tradycję z nowoczesnością, kulturę wspólnotową z kulturą korporacyjną, poszukuje kompromisu między sprzecznymi z sobą i często nie do pogodzenia interesami różnych grup nacisku (s. 117).

Autorka porusza także całe spektrum zjawisk związanych z patologiami życia akademickiego. Rozdział domyka charakterystyka specyfiki studiów pedagogicznych i roli pedagoga w rzeczywistości społecznej. Podkreślić należy profesjonalizm autorki w redagowaniu treści, znawstwo problematyki i prezentowanie jej w bardzo szerokim i wielowymiarowym ujęciu z uwzględnieniem przemian historycznych oraz aktualnych trendów 
i kierunków zmian. Ta część pracy stanowi solidne podłoże pod koncepcję badań, którą autorka przedstawia w czwartym rozdziale.

Polski uniwersytet zdaniem Doroty Pauluk:

[...] przypomina model hybrydowy, gdyż łączy z sobą sprzeczne i często nie do pogodzenia elementy. Uniwersytet staje się miejscem, w którym dochodzą do głosu przeciwstawne oczekiwania i interesy różnych podmiotów (studentów, kadry nauczającej, pracodawców, przedstawicieli środowisk biznesowych). Wszystko to tworzy dobre warunki do rozprzestrzenienia się ukrytego programu (s. 137).

Celem podjętych badań czyni: „rozpoznanie ukrytych programów uniwersyteckiej edukacji i ich rezultatów w doświadczeniach studentów pedagogiki jednego z polskich uniwersytetów” (s. 137). Stawia wobec tego następujący problem główny: „Jakie są ukryte programy uniwersyteckiej edukacji i ich rezultaty $\mathrm{w}$ doświadczeniach studentów pedagogiki?" (s. 137). Autorka w wyniku analizowanego materiału empirycznego wyłoniła siedem problemów szczegółowych. Jednak w wyniku procesu kodowania i prowadzonej analizy jakościowej dokonała modyfikacji przyjętych kategorii i stworzenia klucza kategoryzacyjnego zawężonego do czterech kategorii nadrzędnych (i podkategorii i treści uzupełniających), tj.: studia jako uczenie się życia, studia jako uczenie się bycia ekspertem, studia jako uczenie się roli studenta w wyniku działania ukrytych programów uniwersyteckiej edukacji oraz uczenie się funkcjonowania w instytucji społecznej (uniwersyteciej) (s. 151152). Prezentacji i analizie tych kategorii poświęcone są cztery rozdziały empiryczne. Konstrukcja każdego z rozdziałów, zawartość treściowa oraz przejrzystość prezentowanych danych empirycznych potwierdzają wnikliwość i rzetelność badawczą Doroty Pauluk.

Przestawiony w monografii materiał empiryczny stanowi cenne źródło wiedzy na temat stosunku studentów do studiów jako zarówno etapu kształcenia, jak i okresu rozwojowego. Zastrzeżenie budzi jednak założenie autorki o tym, że uczenie się określonych ról (studenta, eksperta) oraz rozwój osobowy studenta są rezultatami programów ukrytych, przedstawione zarówno w postaci problemów szczegółowych, jak i tytułów rozdziałów empirycznych. Rezultaty chociażby odnoszące się do sfery życia osobistego studenta, jego przygotowania do wyzwań dorosłości, jak podkreśla sama badaczka, „stanowią kombinację czynników podmiotowych, akademickich i pozaakademickich" (s. 177). Część tych efektów może wynikać właśnie z oddziaływania oficjalnego programu kształcenia, co przyznaje sama Dorota Pauluk. Studenci choć:

[...] dostrzeganych u siebie pozytywnych zmian raczej nie odnoszą do sformalizowanej edukacji, to ich język, często nieświadome odwoływanie się do różnych teorii pokazują jednak rolę i znaczenie tego wpływu. Jakkolwiek studenci mocno dystansują się do wiedzy akademickiej, poddają surowej krytyce, [...], to zapewne i ona odpowiada za kształtowanie ich jako osób o domykającej się tożsamości indywidualnej, o czym tak często wspominają w esejach (s. 179-180). 
Na podkreślenie zasługuje fakt przedstawiania portretu własnej osoby przez samych studentów głównie w pozytywnym świetle i jednocześnie częstego negowania bądź pomniejszania roli edukacji akademickiej w ich rozwoju osobowym.

Jest to szczególnie dostrzegane w treściach rozdziału szóstego, Uczenie się roli eksperta jako rezultat ukrytych programów uniwersyteckiej edukacji pedagogów. Oczekiwania studentów zderzają się uniwersytecką rzeczywistością, co daje upust w postaci rozczarowania i frustracji oraz obaw o przyszłość zawodową. Jest to efekt wielowymiarowych uwarunkowań składających się zarówno na jakość edukacji akademickiej, jak i specyfiki pokolenia Y nastawionego na pragmatyzm i uzyskanie w krótkim czasie wymiernych wyników. Młode pokolenie $\mathrm{w}$ dobie przeładowania informacyjnego nie chce „zaśmiecać” swoich umysłów zbyteczną w ich mniemaniu wiedzą. Można przecież w każdej chwili mieć dostęp do informacji. Jak podaje jedna ze studentek w swoim eseju: „studia uczą przede wszystkim przyswajania milionów definicji, które w życiu codziennym i przyszłej pracy są kompletnie nieprzydatne, ponieważ dla przyszłego pracodawcy nie będzie się liczyć to, czy ja będę potrafiła przytoczyć myśl tego czy innego myśliciela" (s. 193). Takie myślenie o edukacji akademickiej jest obecne u wielu studentów, co potwierdzają liczne badania innych badaczy.

W rozdziale siódmym, Uczenie się roli studenta jako rezultat ukrytych programów uniwersyteckiej edukacji, autorka ujawnia strategie adaptacji do życia w uniwersytecie studentów, którzy wstępując w progi uczelni, niejednokrotnie mają poczucie osamotnienia. Dzięki opisanym w esejach doświadczeniom studenckim można uzyskać wiedzę o organizacji przestrzeni akademickiej, metodyce nauczania, nieformalnych oczekiwaniach nauczycieli akademickich, strategiach uczenia się i relacjach panujących w grupie rówieśniczej.

Pozostaje pewien niedosyt $\mathrm{w}$ prezentowaniu materiału empirycznego $\mathrm{z}$ racji jego obszerności (319 esejów). Pomimo że autorka dysponuje swobodnymi wypowiedziami wszystkich roczników studiów pedagogicznych, nie ujawnia w rozprawie, czy między studentami studiów licencjackich i magisterskich są różnice $w$ ich stosunku do edukacji akademickiej. Ciekawe poznawczo wydaje się uzyskanie odpowiedzi na pytanie chociażby o to, jak postrzegają studia studenci pierwszych i ostatnich roczników. Nie było to konieczne z racji przyjętej koncepcji badań, jednak pozwoliłoby na uchwycenie, być może, pewnych różnic w postrzeganiu edukacji wyższej przez młodzież akademicką. Mam świadomość ogromu poczynionej przez badaczkę pracy - analizowania wielokrotnego często rozbudowanych treściowo esejów, konieczności selekcjonowania treści i ich uporządkowania pod katem przyjętych kategorii. Dokonane podsumowania każdego rozdziału empirycznego są dowodem na rzetelne i wnikliwe przestudiowanie materiału empirycznego oraz wysoką świadomość metodologiczną autorki w zakresie programów ukrytych. Każde $\mathrm{z}$ tych podsumowań jest przedstawione w syntetyczny i przejrzysty sposób w postaci tabeli zawierającej wybrane aspekty ukrytego programu zrekonstruowane na podstawie wypowiedzi studentów.

Ostatni z rozdziałów, Strategie radzenia sobie na studiach jako reakcja zwrotna studentów pedagogiki na ukryte programy uniwersyteckiej edukacji, to istotne źródło wiedzy o kreowa- 
niu przez studentów własnej wersji ukrytego programu. Treści tego rozdziału pierwotnie miały stanowić podkategorię „uczenie się strategii radzenia sobie na studiach” do kategorii „uczenie się roli studenta”. Z uwagi jednak na opisywanie przez zdecydowaną większość studentów różnych stosowanych przez nich działań, autorka uznała za konieczne (i słusznie) wyszczególnienie tej problematyki w oddzielnej części pracy. W ramach zawartości treściowej tego rozdziału Dorota Pauluk ujawnia "twarde” i „miękkie” strategie działań nierozwojowych i nieetycznych studentów, jak i „edukację patchworkową” jako odpowiedź na luki w kształceniu i wykształceniu akademickim, błędy organizacyjne, mało zadowalającą ofertę studiów czy też poczucie studiowania mało poważnego kierun$\mathrm{ku}$. Wiele z tych opisów pokrywa się z charakterystycznymi nieetycznymi działaniami studentów opisanymi w pracach badawczych innych autorów. Przykładem jest chociażby monografia Agnieszki Gromkowskiej-Melosik Ściagi, plagiaty, fałszywe dyplomy (Gdańsk 2007). Dowodzi to tylko faktu, że zjawisko rozmijania się interesów uczelni i studentów zaczyna się nasilać, czego efektem są m.in. poszerzające się patologie życia akademickiego, o których piszą w swoich pracach np. Zbigniew Kwieciński i Piotr Sztompka.

Edukacja akademicka zawiera w sobie wiele sprzeczności, jednak nie można jej rozpatrywać w oderwaniu od szerszego kontekstu zjawisk społecznych, na co w końcowych wnioskach wskazuje autorka pracy:

Instytucje akademickie nie funkcjonują w próżni. Uniwersytet poddawany jest oddziaływaniom szerszego kontekstu społecznego. Jego funkcjonowanie zależy od polityki oświatowej, sytuacji ekonomicznej, społecznej itp. Sprzyjający rozprzestrzenianiu się ukrytych programów hybrydalny model współczesnego uniwersytetu, w którym próbuje się łączyć sprzeczne interesy wielu podmiotów [...], tradycję z nowoczesnością (s. 289).

Ta sprzeczność widoczna jest na wielu poziomach edukacji akademickiej, jak również w rzeczywistych rezultatach studiów, jakimi są negatywne i nieetyczne strategie radzenia sobie na studiach. Jak zauważa Dorota Pauluk:

W 319 esejach nie pojawiła się ani jedna ocena potępiająca takie zachowania jako sprzeczne z zasadami moralności, etyki, a można było natomiast znaleźć jeden głos mówiący o samooszukiwaniu się (s. 267).

Autorka pomimo oparcia swoich badań jedynie na narracjach studentów zachowuje obiektywizm i krytyczną refleksję wobec ujawnionych zjawisk. W rozbudowanych Uogólnieniach $i$ wnioskach końcowych wskazuje na różne ich uwarunkowania, analizuje je w odniesieniu do szerokiego spektrum zachodzących zmian zarówno w środowisku akademickim, jak i tych dziejących się w bliższym i dalszym kręgu odniesienia. Podkreśla, że:

[...] wypowiedzi zdradzają, że są jednak wymiary ukrytości, którymi nie chcą [studenci - M.M.] się dzielić, o których rozmawiają tylko między sobą, ponieważ dotyczą na przykład zbyt drażliwych tematów. To treści dotyczące postaw i zachowań, które mogłyby pokazać ich w zlym świetle, odkrywać 
zachowania ryzykowne niekiedy zakazane przez prawo, czy które zbyt dużo mówiłyby o ich nieuczciwości (s. 276).

Poczynione analizy, przytoczone fragmenty esejów i wnioski Doroty Pauluk skłaniają do refleksji nad kondycją edukacji wyższej uwikłanej w szereg niekorzystnych zjawisk oraz świadomością rozwojową podmiotów tej edukacji, tj. studentów. Duża wartość poznawcza rozprawy, walory metodologiczne i merytoryczne sprawiaja, że jest cennym źródłem wzbogacającym wiedzę z zakresu pedagogiki szkoły wyższej. Polecam ją wszystkim badaczom i praktykom, którzy w centrum swoich zainteresowań umieszczają programy kształcenia oraz podnoszenie efektywności edukacji nie tylko na poziomie studiów wyższych. Publikacja może stanowić też ważny wkład w podjęcie debaty nad szkołą wyższą i jej rolą w tworzeniu społeczeństwa wiedzy. 